\title{
MELINTAS
}

31.1.2015 [31-46]

\section{VATIKAN II SETELAH 50 TAHUN: QUO VADIMUS}

\author{
Fabianus Sebastian Heatubun \\ | Department of Theology \\ Faculty of Philosophy \\ Parahyangan Catholic University \\ Bandung, Indonesia
}

\begin{abstract}
:
Pope Francis's statement "I am the Vatican II" sounds a manifesto. To which direction is the wind blowing the Church's ark, we might have already guessed. The existing dichotomy between the liberal and the conservative as well as the tension between the primacies of the pastoral and the dogmatic will yet be conflicting and colliding with each other. After 50 years, the $2^{\text {nd }}$ Vatican Council and the ongoing future discussions about the basic pastoral directions within the Catholicism are to this day white-hot. The Pope could be anyone. But theologians, for these are who make the lineamenta of a new document, will continue to colour the trend of the Church in giving responses to the signs of the time. The future of Catholicism will not be viewed as limited as the lens of the Vatican II. The future humanism will challenge the Church with wider and more complex considerations rather than dwelling on the problems of dialogue with other religions apologetically or racketing with traditionalism, liberalism, and sekularism. There are pressing matters such as ecology, global warming, terrorism, and the sprawling gap between the poor and the rich. Macro-ethics has become more imperative than micro-ethics. The Catholic Church is called out to create "a better world for all" - the Kingdom of God that is inclusive and at a stroke pluralistic.
\end{abstract}

Keywords:

bermeneutics - orthodoxa • bonum universalis • relativism • heretical interpretation • renewal in continuity • macro-ethics • micro-ethics 


\section{Status Quaestionis}

Dalam memperingati 50 tahun Vatikan II masih berjejalan dan berseliweran pertanyaan-pertanyaan yang datang dari berbagai kubu. Pertanyaan-pertanyaan memenuhi ruang sidang dengan memperkarakan dan memperdebatkan esensi dan eksistensi dari 16 dokumen hasil sidang Ekumenis Vatikan II itu. Pertanyaan dan pernyataan yang penuh dengan cemooh dan kritik. Demikian juga pernyataan-pernyataan apologetik sebagai jawaban, yang kian melahirkan kembali sejumlah pertanyaanpertanyaan yang baru - pertanyaan-pertanyaan yang lebih menyulitkan. Vatikan II adalah problem. Dari kubu konservatif Katolik, Vatikan II dianggap 'antikristus.' Dari kubu nonkatolik muncul anggapan bahwa Vatikan II mendiskreditkan keyakinan orang lain meski secara eufemistik mengatasnamakan 'dialog.' Dari kubu liberal, Vatikan II dianggap kuno dan ketinggalan zaman. Sedangkan, dari kubu moderat, dianggap sebagai hasil usaha dan kerja keras yang perlu dirayakan, disyukuri, dan dijadikan monumen. Vatikan II dianggap prasasti yang agung yang pernah ada dalam perjalanan sejarah Gereja dan peradaban manusia. Sebuah magna charta kelas dunia.

Bulan Juni 51 tahun lalu adalah hari pertama Paus Paulus dinobatkan sebagai Paus terpilih tatkala sidang Konsili Ekumenis Vatikan II belum selesai. Di berbagai tempat dan kesempatan telah berkumpul berbagai kalangan untuk membicarakan Konsili Vatikan II yang telah menjadi sejarah. Ada diskusi yang hangat dengan sudut pandang pertanyaan dan perdebatan yang berbeda, namun esensinya senada. Pertanyaan Quo vadis? mengandaikan bahwa pertanyaan itu ditujukan kepada Konsili Vatikan II itu sendiri sebagai sebuah entitas, sebagai sebuah hasil refleksi yang dirumuskan dengan bobot teologis. Kita merasa patut untuk menanyakan karena kita telah mengalami, merasakan, dan mimilih 'cara hidup' dan 'cara berpikir' religiusitas kita dengan paradigma Konsili Vatikan II. Engkau akan ke mana Vatikan II? Engkau akan berjalan sendiri? Bagaimana kalau kami tinggalkan? Bagaimana kalau kita revisi? Pertanyaan Quo vadimus? Kita mau ke mana? - mengandaikan pertanyaan kepada diri 'kita' sendiri, kepada Gereja Katolik. ${ }^{1}$ Ini pertanyaan yang baik untuk dijawab bersama. Sadar atau tidak, isi Konsili Ekumenis Vatian II telah memformat kita, ke arah paradigma apa yang akan dipakai sebagai peta dan pola hidup menggereja dan bermasyarakat. Pertanyaannya tentu saja harus melampaui 
jenis pertanyaan reflektif seperti 'apa hasilnya', 'apa dampaknya sampai hari ini', 'apakah sudah diresepsi dan diterima dengan baik', 'apakah sudah ditelaah dan dipahami dengan baik dan benar', 'apakah ada penafsiran yang tidak utuh dan salah selama ini.' Vatikan II yang dipandang sebagai sebuah doktrin (orthodoxa) yang merupakan landasan filosofis dan teologis untuk hidup menggereja sebagai communio, sebagai homo religiosus atau sebagai orang beriman memang perlu dikritisi.

Vatikan II itu seumpama "GPS” (Global Positioning System). Ketika kita hidup di dunia yang dijelimeti sejumlah jalan-jalan yang membingungkan, di setiap langkah yang kita jalani selalu dijumpai persimpangan-persimpangan. Pada saat seperti itu kita membutuhkan kepastian, kemantapan, dan kemungkinan yang mencerahkan. Konsili Vatikan II sebagai sebuah GPS di tangan, mestinya memberi petunjuk yang tidak menyesatkan. Pertanyaannya adalah apakah GPS ini sudah tidak mampu lagi memberi petunjuk yang pasti, karena jalan-jalan sudah semakin rumit? Kompleksitas jalan tidak dapat terkuasai atau terkontrol lagi oleh GPS. Kitab Suci (Injil) adalah kompas, sebuah pedoman arah yang menunjukkan tempat yang kita tuju, yakni hidup abadi. Sebuah kompas dengan ketetapan dan kepastian dalam mengarahkan kita tidak perlu diragukan, namun dalam kenyataan tidak ada jalan yang lurus sama sekali. Tidak ada jalan yang lempang, lengang, dan tanpa hambatan. Bahkan, jalan kehidupan kita ini dilingkupi dengan labirin. Meski kita memegang kompas dan tahu arah, namun untuk menelusuri jalan yang akan kita tempuh, itu butuh GPS. Vatikan II adalah sebuah "GPS" yang paling membantu untuk mencapai arah yang telah ditunjukkan oleh kompas. Pertanyaannya adalah: apakah GPS itu masih berfungsi dengan baik?

\section{Pelaku Sejarah Menentukan Karakter Vatikan II}

Secara diakronik ${ }^{2}$ kita dapat menafsirkan realitas sebelumnya maupun yang sesudahnya berdasarkan suatu periode waktu tertentu yang berfokus pada peran pelaku sejarah pada waktu itu. Selain pelaku sejarah juga ada lingkaran-lingkaran (circles) sebagai suatu gerakan serta jurnal-jurnal dan penerbitan yang merupakan representasi dari pikiran-pikiran mereka. Begitu pula kita akan dapat menangkap tren, arah yang berkembang ke depan, berdasarkan dokumen-dokumen pasca-konsilier. Dari sudut pandang ini kita coba mendiagnosis teks dan konteks Vatikan II. 
Teologi Vatikan II atau pasca-konsilier dapat dilihat dari cerminan pemikiran teologis tiga paus: Yohanes Paulus II, Benedictus XVI, dan Fransiskus. Yohanes Paulus II dan Benedictus XVI masih berkisar pada Vatikan II, sedangkan Fransiskus meski masih sumir untuk diduga arah sikapnya, namun dari sejumlah pernyataanya secara spontan tampak masih kuat erat dengan Vatikan II, misalnya, dengan pernyataanya yang provokatif "I'am Vatican II." Yohanes Paulus II dan Benedictus XVI masih konsisten dengan Vatikan II karena mereka berdua adalah arsitek dan sekaligus eksponen dari Konsili tersebut, meskipun Benedictus XVI tidak merasa puas dengan Konstitusi Pastoral Gaudium et Spes. Benedictus XVI sampai mengakhiri jabatannya tetap memplot ulang tahun Vatikan II dengan mengeluarkan Porta fidei. Dia menganggap perlunya penafsiran yang benar dan tepat, yang ada hubungannya dengan aplikasi konkret. Vatikan II dianggap lemah implementasinya karena adanya kekeliruan penafsiran. Berarti dalam hal ini Vatikan II itu berstatus sebagai teks yang terbuka untuk ditafsirkan, yang menuntut penafsiran yang benar.

Ada dua jenis hermeneutik yang telah dipakai menafsirkan teks-teks Vatikan II. Yang pertama disebut "hermeneutic of discontinuity and rupture," penafsiran yang mendapat simpati dari media massa, yang merupakan sebuah tren dalam teologi modern. Yang kedua, disebut "hermeneutic of reform", pembaharuan dalam keberlanjutan dari subjek Gereja yang telah diberikan Tuhan kepada kita. Sayangnya, hermeneutik jenis ini membuat kerenggangan dan pemisahan antara 'pra-konsilier', 'konsilier' dan pascakonsilier. Dengan diadakannya konsili Vatikan II tidak berarti menolak dan menganihilasi konsili-konsili sebelumnya. Gereja sebagai subjek yang bertumbuh kembang dalam waktu, tetap sama sebagai subjek umat Allah yang berziarah. Problem Vatikan II lebih merupakan masalah interpretasi. Bagi kelompok tradisionalis konservatif ekstrim yang diketuai Marcel Lefebvre (Kelompok Pius XI), Vatikan II merupakan konsili yang paling menyesatkan, sebagai suatu revolusi antikristus. Paus-Paus seperti Yohanes XXIII dan Paulus VI dianggap bukan sebagai paus yang sah. Keadaan Gereja dianggap sebagai 'sede vacante.' Vatikan II dianggap sudah menjadi momen antikatolisisme, dan serentak hasil dari Vatikan II itu telah dengan sendirinya dianggap menciptakan agama atau sekte baru. Katolisisme pasca-Vatikan II dianggap bukan Katolik lagi. 
Joseph Ratzinger yang kelak menjadi Benedictus XVI, sebagai professor dari Universitas Bonn, diminta oleh pakar teologi dan Kitab Suci Kardinal Joseph Frings dari Cologne Jerman, yang berusia 76 tahun dan nyaris buta itu, untuk berperan dalam proses perumusan dokumen-dokumen Vatikan II. Ratzinger muda sangat moderat karena berteman dekat dengan Hans Küng yang dikenal sebagai teolog yang liberal dan reformis dari Universitas Tübingen. Pemikiran yang menekankan pentingnya dialog dengan agama-agama lain dianggap termasuk kaum ateis. Di kelak kemudian hari, setelah Vatikan II usai, persahabatan mereka retak dan Ratzinger sendiri yang melarang Küng untuk mengajar. Ratzinger kelak bersahabat erat dengan Karol Wojtyla yang dianggap konservatif. Ratzinger gencar mempromosikan Karol Wojtyla untuk menggantikan Paus Paulus VI, dan ia kemudian menjadi Paus Yohanes Paulus II. Ratzinger perlahan-lahan menjadi konservatif, meski tergolong masih moderat. Sebelum berumur 50, Ratzinger sudah menjadi seorang kardinal di Munich Freiburg, dan ia dipilih oleh Yohanes Paulus II. Tak lama kemudian, Ratzinger dipilih untuk menjadi prefek CDF (Congregation for Doctrine of Faith, atau Congregatio pro Doctrina Fider), yang secara peyoratif kadang-kadang diasosiasikan dengan lembaga 'inquisisi' modern à la Romawi, dan berperan mengadili mereka yang dianggap keluar rel atau tidak sejalan dengan ajaran Katolik. Lebih persisnya, mereka yang disasar itu dianggap bertentangan dengan ortodoxi yang sudah dijabarkan dalam dokumen-dokumen Vatikan II. Posisi sebagai Prefek CDF ini sudah dapat kita tebak ke mana akan mengarahkan irama teologi yang akan diterapkan sepanjang kepemimpinan Yohanes Paulus II dan saat Ratzinger kemudian menjadi Benedictus XVI pada pasca-Vatikan II.

Yohanes Paulus II, yang meninggal pada 2005, segera digantikan oleh Ratzinger. Konon nama Mario Bergoglio merupakan saingan beratnya ketika proses konklaf berlangsung. Ratzinger sudah jelas arah teologinya akan ke mana. Ia bukan melanjutkan warisan pemikiran Yohanes Paulus II, tetapi karena sejak awal Yohanes Paulus II tampil di atas panggung mengikuti skenario yang sudah disusun oleh Ratzinger. Sulit untuk memilah antara kedua Paus ini di kelak kemudian hari. Tiga dari 14 ensiklik penting yang dibuat oleh Yohanes Paulus II antara lain Laborem excercens (1984), sebagai suatu kebiasan dalam peringatan setiap satu dasawarsa dari dokumen ajaran sosial Gereja. Berarti dokumen ini dikeluarkan untuk memperingati 
ulang tahun ke 90 dari Rerum novarum-nya Paus Leo XIII. Dokumen yang membahas tentang karya manusia; Solicitudo rei socialis (1987), peringatan ke 20 tahun Populorum progresio yang berurusan dengan ajaran sosial Gereja; Centesimus annus (1991), dalam rangka peringatan ke 100 tahun dari Rerum novarum; Ut unum sint (1995), suatu ikhtiar untuk kesatuan (sui juris) dengan Gereja Ortodoks dan berdialog dengan Protestan. Sejumlah dokumen yang bersifat ad extra. Setelah merasa mantap dengan urusan-urusan ke dalam (ad intra), Yohanes Paulus II cukup memberi perhatian pada ajaran sosial Gereja. Dokumen-dokumen tersebut ada di tangan Ratzinger sebagai pembuat draft, atau orang lain di bawah pengawasannya.

\section{Pastoral vs. Dogmatis}

Paulus VI menekankan prinsip atau hakikat dari konsili bersifat pastoral, khususnya pada Gaudium et Spes. Paulus VI menegaskan bahwa konsili ini pertama-tama hendak menegaskan hakikat dari Gereja dan persisnya tentang otoritas hierarki dan hakikat dari episkopat. Tentang hal ini lebih rinci diuraikan dalam Christus Dominus dan pertama-tama dalam Lumen gentium bab III. Meskipun bersifat pastoral, tak terhindarkan di dalamnya tersimpan bobot doktriner dan bahkan bersifat dogmatik, terutama ketika digarsibawahi hakikat episkopat itu bersifat sakramental ${ }^{3}$. Di situ otoritas hierarki, dalam hal ini Paus, bersifat "infalible." Bagi Paulus VI, Vatikan II lebih bersifat memperbaharui (renewal) Gereja, bukan merupakan reformasi ataupun transformasi. Dari ide ini jelas bahwa secara keseluruhan Vatikan II ini tidak bermaksud untuk menentukan keputusankeputusan yang sifatnya dogmatis. Paulus VI dianggap oleh pengamat sebagai Paus yang terlalu menyederhanakan hasil konsili. Ini ditengarai dari sikapnya yang ambigu ${ }^{4}$ antara pro dengan yang tradisionalis dan ambisinya dengan kebaruan Gereja, persisnya keterbukaan Gereja pada dunia kontemporer. Paling tidak, terlihat dalam kerinduannya menafsirkan lebih jauh terminologi aggiornamento dari pendahulunya Yohanes XXIII. Paulus VI dapat dianggap paling toleran terhadap agama lain dibandingkan dokumen Vatikan II khususnya dalam Evangelii nuntiandi. Dalam surat ensikliknya Ecclesiam suam, suatu dokumen yang dibuatnya setelah satu tahun menjabat Paus, dinyatakan bahwa pada agama-agama lainpun patut dihargai nilai-nilai moral dan spiritualnya karena hakikatnya sama dengan yang diyakini oleh Gereja. ${ }^{5}$ Mengakui sebagai sama dan sejajar dengan 
agama lain ini dianggap sesuatu yang melampaui pandangan Vatikan II. Evangelii nuntiandi menganggap agama lain itu sama-sama mengarah pada keselamatan namun keselamatan dari agama lain itu bersifat biasa (ordinary) sedangkan dalam Kristianitas luar biasa (extraordinary). ${ }^{6}$ Paulus VI memandang Vatikan II sebagai upaya merestorasi kesatuan umat Kristen pada umumnya dan mengakui kesalahan juga bila Gereja Katolik berkontribusi sehingga terjadi perpisahan. Ia tidak menyalahkan pihak lain. Spirit Vatikan II adalah dialog dan negosiasi. Hanya dengan berdialog akan dipecahkan masalah dan konflik, itulah yang diyakini Paulus VI.

Selain Paulus VI yang menggradasikan Vatikan II pada level pastoral, ada pula sejumlah orang dan kelompok yang anti terhadap hasil Vatikan II itu dan yang menganggapnya sebagai instruksi-instruksi pastoral belaka. Reaksi atas penolakan ataupun ketidaktaatan pada ketentuan Vatikan II itu telah menyebabkan sejumlah teolog dilarang mengajar, misalnya Hans Küng, Charles Curran, Leonardo Boff, Tissa Balasuriya, Jaques Dupuis, dan sebagainya. Mereka ini dianggap menyeleweng. Peristiwa dramatik ekskomunikasi atas Marcel Lefebvre dan pengikutnya adalah fenomena yang menunjukkan sikap defensif Vatikan II. Begitu pula asosiasi seperti Una Voce, Opus Sacerdotale, Credo, Silenziosi della Chiesa, meskipun kelompokkelompok ini tetap taat kepada keputusan hierarki, namun menganggap keputusan Vatikan II itu tidak berdimensi dogmatis, dan dikatakan Vatikan II bersifat pastoral belaka, yang pada gilirannya dokumen-dokumennya tidak sangat mengikat.

Ada penafsiran yang tidak seragam diantara paus-paus, para teolog dan komunitas-komunitas dalam Gereja Katolik atas hasil Vatikan II. Ada pula yang menganggap bahwa Vatikan II baru berupa bahan mentah yang perlu ditindaklanjuti, dijabarkan dan/atau ditafsirkan ulang. Vatikan II dianggap belum selesai, kerena sejumlah eksponen yang terlibat dalam perencanaan, pelaksanaan, dan pasca-perumusan pun masih berikhtiar untuk mengeksplorasi terus menerus. Jaques Maritan, Jean Danielou, Henri de Lubac dan Hans Urs von Balthasar merasa cemas bila Gereja Katolik akan jatuh ke dalam sekularisme serta akan menggerogoti otoritas Gereja bila hanya berpegang pada doktrin-doktrin yang ada dalam Vatikan II - suatu keyakinan yang tidak beda jauh dengan kelompok Tradisionalis yang merasa pesimis. Misalnya, apakah Gaudium et spes dapat diterima dengan terbuka sebagai sebuah dokumen yang menjadi pedoman bagi Gereja Katolik yang hidup di dunia riil masa kini? Lebih persisnya, dapatkah Vatikan II menjadi 
'perisai' untuk menangkal serangan dari dunia yang semakin sekuler ini? Apakah Gaudium et spes tidak justru menjadi bumerang bagi kristianisme itu sendiri? Sejajar dengan pemikiran tradisionalis yang skeptis dan bahkan anti dengan Vatikan II menerapkan logika post hoc ergo propter hoc (kirakira artinya; sesudah ini, jadi ini yang menyebabkannya). Perubahan terjadi justru setelah Konsili Vatikan II, jadi Konsili-lah yang menyebabkannya. Konsili Vatikan II dianggap yang menyebabkan katolisitas, realigiositas, serta otoritas Gereja jadi merosot dan mengalami kemunduran. Alih-alih dipakai untuk menangkal dan menyelamatkan katolisitas, justru Vatikan II inilah yang merusak dan menggerogoti tubuh Gereja sendiri.

Joseph Ratzinger dan Henri de Lubac tetap menjadi oposan atas isi Gaudium et spes khususnya. Mereka yang Agustinian itu sangat curiga dengan modernisme. Keduanya, meskipun skeptis dan pesimistik terhadap Vatikan II, tentunya tidak seekstrem Lefebvrian yang menolak semua hasil konsili. De Lubac tetap loyal tetapi lebih berupa kepasrahan akan optimisme yang berlebihan terhadap modernisme. Santo Agustinus dengan Kota Allahnya telah mempengaruhi pemikiran Ratzinger dan Lubac. Kota Allah yang mengartikan Gereja itu menjadi semacam antitesis dari dunia yang dianggap mursal dan jahat. Gereja di dalam dunia modern harus berikhtiar melawan dan menaklukannya, bukan malah berkompromi atau bekerja sama. Para pengamat berpendapat bahwa Ratzinger di kelak kemudian hari berubah pikiran ketika menggali Bonaventura dalam studi postdoktoralnya. Sehingga, ketika dia menjadi Benedictus XVI, ia memahami Gaudium et spes lebih sedikit optimistik dibandingkan dengan Lubac.

Kecurigaan sekaligus kewaspadaan terhadap modernitas itu tentu saja ada sejak Pius IX dan Pius XII, yakni, misalnya, bagaimana Pius IX mendaftarkan apa saja yang dianggap kesesatan-kesesatan secara doktrinal dan politis dalam Syllabus Errorum (1864). Ini adalah daftar hal-hal yang harus ditolak seperti tentang panteisme, naturalisme, rationalisme, sosialis komunisme, liberalisme, dan sebagainya. Sifat defensif Vatikan II juga masih sama, tidak sangat berubah.

Beberapa teolog yang lebih moderat seperti Dossetti, Alberigo, menganjurkan agar menafsirkan Vatikan II itu bukan hanya dari sisi implementasi secara literal saja tetapi juga mesti dilihat spirit di balik dokumen-dokumen tersebut. Meskipun begitu tersimpan pertanyaan: apakah berarti telah terjadi kegagalan dalam merumuskan spirit dan 
maksud yang baik ke dalam perumusan dokumen-dokumen Vatikan II sebagai teks? Demikian juga Yves Congar menganggap sesuatu yang keliru bila sikap Gereja menganggap dunia itu harus ditaklukan atau dikuasai. Dunia itu harus diperlakukan sebagai anak yang harus diurus, dibesarkan, dididik, dan dijadikan baik. Bagi Congar Gereja berelasi dengan dunia untuk melayaninya. Selain mewartakan Injil ke tengah-tengah dunia, juga harus melayaninya hingga akhir zaman, karena Gereja dan dunia itu akan mejadi satu. ${ }^{?}$

Vatikan II, khususnya seperti Gaudium et spes merupakan wujud dari ikhtiar untuk memberi bingkai kembali kepada Katolisitas sejati yang menyimpan kebenaran iman (depositum fider), sebagai suatu upaya teologis yang mencoba lebih setia kepada Injil daripada kepada sebuah budaya, sosiologi atau sebuah ideologi. Gaudium et spes diharapkan menjadi cara menggereja di dalam dunia yang mendunia dan berdialog dengan realitas riil. Cita-cita bonum commune dan bonum universalis diharapkan merupakan dampak dari Gaudium et spes itu.

\section{Paus Fransiskus: “Akulah Vatikan II"}

Jorge Mario Bergoglio yang ditahbiskan menjadi imam tahun 1969, paling tidak baru berusia 25 tahun ketika Konsili Vaikan II selesai. Dia bukan eksponen, bukan drafter apalagi arsitek Vatikan II. Bergoglio hidup di Argentina, Amerika Latin, yang jauh dari hingar bingar Eropa yang mendiskusikan dan memperdebatkan esensi dan eksistensi Vatikan II. Dia pasti mendengar meski tidak punya perhatian khusus, baru pasca-Vatikan II. Pemilihan dan penobatan Bergoglio menjadi Paus Fansiskus secara implisit sudah memperlihatkan ke arah mana Vatikan II dibawa. Dengan kata lain, akan ada penafsiran baru atas Vatikan II. Tapi apa artinya pernyataan spontan Fransiskus ketika mengatakan "I am the Vatican II"?8 Suatu pernyataan enigmatik yang penuh dengan teka-teki. Sebuah pernyataan yang mengingatkan kita pada Louis XIV raja Prancis (+ 1715), "L'etat, c'est moi" - Akulah negara. Apakah Fransiskus menganggap dirinya sebagai personifikasi Vatikan II? Secara positif hendak diegaskan bahwa Vatikan II itu bukan lagi ada dalam taraf pembicaraan atau diskusi verbal. Fase konseptual dan notional diangap sudah lewat. Vatikan II perlu diejawantahkan atau diinkarnasikan dalam tindakan dan hidup yang nyata? Menjadi "the living Vatican II." Vatikan II harus sudah menjadi 'persona.' 
Teori harus sudah menjadi praksis. Atau, dalam arti negatif, mengenai Vatikan II itu urusan pribadinya dan merupakan bentuk chauvinisme radikal dan absolut akan Vatikan II? Seakan-akan hanya Fransiskuslah sebagai paus yang dapat mengkontrol esensi dan eksistensi Vatikan II, tidak ada pihak manapun baik teolog maupun kelompok tertentu, yang dapat mengendalikan Paus Fransiskus. Pernyataan spontan memang bukan sebuah tulisan resmi yang dikeluarkan dalam sebuah dekret, namun pernyataan itu transparan untuk kita tebak seperti apa sikapnya atas Vatikan II.

Peristiwa kanonisasi Yohanes XXIII dan Paulus VI secara jelas menunjukkan suatu afirmasi atas hasil Vatikan II. Sang pencetus ide aggiornamento dan Paulus VI yang menandatangi setiap dokumen Konsili Vatikan II perlu dijustifikasi dengan kanonisasi sebagai santo. Peristiwa monumental yang setiap orang wajib mengingatnya sebagai 'in illo tempore', pada diri kedua orang suci itulah Vatikan II bersumber dan sekaligus bermuara. Poros peradaban Katolik Roma dimulai dan diputar dari dua pribadi santo tersebut. Begitu pula dalam homilinya di kapel Domus Sanctae Marthae, Paus Fransiskus menyatakan, "Konsili itu merupakan karya yang indah dari Roh Kudus, setelah 50 tahun ini apakah kita telah melakukan semua yang Roh Kudus telah katakan kepada kita?" Suatu pernyataan yang hendak mengatakan bahwa Vatikan II itu sungguh-sungguh karya dan kehendak Roh Kudus, bukan kehendak dan prestasi manusia. Menyangkal atau anti-Vatikan II sama saja dengan melawan Roh Kudus. Injil mencatatnya bahwa "dosanya tidak akan diampuni." Paus Fransiskus sangat mengapresiasi hasil Vatikan II. Dari sikapnya ini terbacalah masa depan Vatikan II. Bukankah eksortasi (anjuran) apostolik Evangelii Gaudium $^{10}$ secara karakteristik hendak menggemakan Konstitusi pastoral Gaudium et spes? - suatu perhatian pada ajaran-ajaran sosial Gereja dalam dunia yang berubah dan berkembang. Dunia ditandai oleh kemajuan sains, tehnologi, dan ideologi modernisme yang materialistis. Kemajuan itu sendiri tidak dikutuk atau dicurgai, apalagi dinegasi, tapi disadari bahwa manusia adalah pusat yang tetap harus dihargai martabatnya. Diingatkan supaya jangan puas dan bangga dengan penemuan tetapi melupakan Allah. Kemajuan tak terhindarkan dan dapat mengancam kesenjangan antara orang kaya dan miskin, perang dan masalah keluarga serta perkawinan. Gaudium et spes menggambarkan upaya berdialog dengan modernitas. 
Dokumen yang dianggap sebagai "Tanah terjanji dari Konsili" oleh Yves Congar itu merupakan hasil kompromi yang alot antara dua kubu progresif (Schillebeeckx beserta teolog-teolog Amerika Latin) dan kubu konservatif (Rahner, Ratzinger, Dosetti, Lubac, Danielou). Bagi yang konservatif dokumen ini dianggap terlalu membuka pintu terhadap modernisme.

"Apalah arti sebuah nama?" kata Shakespeare. Rupanya nama yang dipilih oleh seorang paus sangat sarat dengan makna dan implikasi praktis pada Katolisitas selanjutnya. Yohanes Paulus II memilih nama tersebut karena hendak memadukan visi, misi, dan cita-cita serta spiritualitas Yohanes XXIII dan Paulus VI. Keduanya merupakan penggagas, pengawas dan moderator utama dalam Konsili ekumenis Vatikan II, sehingga dengan bertanya siapakah Yohanes Paulus II itu, jawaban tegasnya adalah bahwa dia ini merupakan fusi dari kedua pendahulunya. Atas nama tradisi yang tak boleh terputus, dalam diri Yohanes Paulus II tampak usaha membela dan mempertahankan cita-cita pendahulunya. Demikian juga, pemilihan nama Benedictus XVI bagi Joseph Ratzinger, memberi kesan keluar dari perhatian pada Konsili Vatikan II. Benedictus dari Nurcia (abad ke-5) adalah seorang rahib yang karena askesenya kuat membuatnya menjadi suci. Benedictus dari Nurcia adalah pendiri dan perintis gaya monastisisme Barat. Dia menjadi akar tunggang yang telah merubah kebudayaan dan peradaban Eropa pada umumnya. Dialah yang membawa terang dalam zaman kegelapan pada waktu itu. Secara metaforis figur ini ingin menjadi riil dalam diri Joseph Ratzinger yang menjadi Paus Benedictus XVI untuk menjadi terang dunia, terutama di Eropa. Tidak terhindarkan di dalamnya tersirat spiritualitas yang konservatif. Fuga mundi yang dilakukan Benedictus dari Nurcia menggambarkan seorang Ratzinger yang harus melakukan negasi atas dunia, paling tidak mencapai pemenuhan cita-cita itu setelah lengser sebagai paus dan mengurung diri sebagai rahib. Benedictus XVI memberi angin segar untuk menghidupkan kembali sejumlah praktik keagamaan dan devosional yang ditinggalkan oleh Vatikan II, misalnya, Misa Latin Tridentinum, praktik eksorsisme, dan pemakaian sejumlah asesoris liturgi pontifikalnya.

Pemilihan nama "Fransiskus" oleh Bergoglio diinspirasi oleh pengalaman revelatif Santo Fransiskus Assisi di hadapan salib San Damiano. Fransiskus Assisi dipanggil untuk menyangga Gereja yang akan rubuh. Ini bukan hanya akan dijadikan inspirasi mengenai kemiskinan dan 
kesederhanan serta sifat dialogisnya dengan musuh perang salib (Shaladin), tetapi pertama-tama keyakinan Bergoglio yang menganggap Gereja Katolik akan rubuh bila tetap berkutat dalam spiritualitas yang duniawi. Paus Fransiskus sangat dipengaruhi oleh Henri de Lubac, SJ., mungkin salah satu alasannya karena setarekat sehingga Fransiskus menjulukinya sebagai homo ecclesiasticus, seorang 'gerejawan.' Sebutan yang serupa kita pakai juga untuk membedakan antara seorang 'politikus' atau seorang 'negarawan.' Fransiskus menimba inspirasi hidupnya dari buku De Lubac, The Splendor of the Church, ${ }^{11}$ khususnya mengenai ancaman 'spiritualitas duniawi.' Di edisi terakhir, Fransiskus sendiri yang memberi pengantar yang lebih berupa sanjungan. Sebenarnya buku itu disitir oleh Yohanes Paulus II dalam ensikliknya Redemptor hominis. Itu seperti Benedictus XVI yang juga memuji-muji De Lubac dan Balthasar sebagai tokoh-tokoh yang memberi pengajaran teologis dan humanistik yang komprehensif serta penting bagi Katolisisme. Menjadi suatu indikasi tertentu bahwa Henri de Lubac oleh ketiga paus setelah Vatikan II tetap menjadi dasar visi magisterial mereka. Dengan kata lain, sulit untuk mengatakan bahwa ketiga paus pasca-Vatikan II itu bukan 'Lubacian', yang berarti konservatif.

\section{Tantangan Vatikan II untuk Masa Kini}

Bila dalam Vatikan II yang dihadapi sebagai ‘lawan' adalah rasionalime dan modernisme, kini Gereja menghadapi postmodernisme yang oleh Benedictus XVI dianggap seteru yang mengancam kebenaran Katolisisme. Menurut Benedictus XVI zaman ini ditandai oleh apa yang disebut "dictatorship of relativism" 12 atau dianggap adanya tirani relativisme yang memupus kebenaran; postmodernismelah yang menjadi 'biang kerok'-nya. Dunia semakin ditandai dengan nihilisme. Kebenaran telah mati. Sementara, kehidupan itu membutuhkan suatu kepastian kebenaran sebagai suatu pegangan. Perlukah mengadakan Vatikan III sebagai upaya antisipatif? Ini suatu pertanyaan. Atau, cukup ditangkal oleh sejumlah teolog dan filsuf postmodern yang konstruktif seperti James K.A. Smith yang secara provokatif menulis Who's Afraid of Postmodernism? Taking Derrida, Lytard, and Foucault to Church ${ }^{13}$ atau Jean-Luc Marion, John Millbank, Catherine Pickstock, Graham Ward, Stephen Long, Tracey Rowland, dan sebagainya? Kelompok ini berikhtiar kembali ke yang telah menjadi akar tradisi dan yang telah dianggap sebagai ajaran kebenaran, meskipun 
sebagian dari mereka bukan dari kubu Katolik. Atau, masih dapatkah diharapkan sisa-sisa eksponen Communio seperti tulisan-tulisan Balthasar, Kasper, Marc Quellet, Bouyer, atau eksponen Concilium yang di dalamnya masih ada tulisan-tulisan Metz, Chenu, Congar, Rahner dan Schillebeeckx? Tulisan-tulisan mereka, meskipun kebanyakan telah meninggal dunia, yang dulu dicurigai dan dianggap kurang Katolik dapat menjadi inspirasi untuk berdialog dengan kaum postmodern. Kehadiran sejumlah dokumen pascakonsilier seperti Porta fidei, Lumen fidei dan Evangelii gaudium memberikan peneguhan tersendiri secara pastoral dalam menghadapi apa yang disebut diktator relativisme.

Mutatis mutandis - Apa atau siapa yang menentukan arah dari Vatikan II itu? Jawaban pertanyaan tersebut, pertama-tama, amat tergantung pada siapa yang memegang peran menyusun lineamenta (sebagai drafter) untuk memandu dan mengarahkan jalan pemikiran pada sebuah dokumen untuk disetujui oleh peserta sidang. Orang yang bersangkutan itulah yang juga berpengaruh menentukan kelanjutan Vatikan II, apalagi ketika mereka yang dahulu ikut menyusun lineamenta tersebut kelak menjadi pausnya, seperti Yohanes Paulus II dan Benedictus XVI. Paus Fransiskus, meski masih konsisten dengan Vatikan II, bisa saja akan memberi arah dan warna baru dalam visi teologis dan pastoralnya. Fransiskus secara pribadi berbeda dengan Benedictus XVI yang lebih scholarly serta lama duduk di belakang meja yang penuh dengan buku-buku. Fransiskus menghabiskan banyak waktunya untuk berkeliaran di tempat-tempat yang kumuh dan bergesekan langsung dengan denyut nadi kehidupan urban di dalam bus kota. Karenanya, sejumlah pengamat berani mengtakan bahwa kini Paus Fransiskus ini akan memberi angin segar kepada Teologi Pembebasan Amerika Latin yang sebelumnya dicurigai dan dilarang karena berbau marxis.

Namun, ada yang perlu diingat. Siapa yang menjadi kepala CDF sekarang? Inipun akan ikut ambil bagian penting dalam menentukan arah kelanjutan Vatikan II. Gerhard Ludwig Müller dipilih oleh Benedictus XVI untuk menjadi "anjing penjaga" yang baru di Vatikan. Müler masih dipakai oleh Fransiskus. Dia adalah murid Gustavo Gutierrez, tokoh penting dalam Teologi Pembebasan Amerika Latin. Müller diangkat sebagai kardinal oleh Paus Fransiskus yang serentak diberi peran penting dalam mengawasi Komisi Alkitabiah Kepausan serta Komisi Teologi 
International dan Komisi Kepausan Ecclesia Dei. Sejumlah komisi yang cukup berpengaruh dalam menentukan arah teologi Katolik (Vatikan). Inisiatif yang paling kentara adalah ikhtiar untuk menjembatani dua kutub yang semakin memanas antara kelompok tradisionalis dan kelompok progresif. Kondisi yang tidak sehat akan mengancam kestuan Gereja itu sendiri. Müler menilai bahwa kedua kutub itu telah melakukan "heretical interpretation" (penafsiran heretik, bidaah) atas Konsili Vatikan II. Müller sependapat dengan Benedictus XVI bahwa sebuah hermeneutika yang baik dan benar seharusnya mencari hal yang paling sesuai dengan prinsipprinsip Katolisitas yang sedang diimani dan berprinsip pada keberlanjutan, yang disebut "the hermeneutic of reform, of renewal in continuity." ${ }^{14}$ Pendapat Müller, meskipun Paus Fransiskus bukan penganut Teologi Pembebasan secara ideologis dan akademis, namun seacara pastoral sangat memperhatikan apa yang dicita-citakan oleh Teologi Pembebasan. Teologi yang baik itu selalu ada aplikasi riil pastoralnya. Paus Fransiskus sudah langsung kepada tindakan nyata. Dalam hal ini Müller juga menengahi dikotomi antara Benedictus XVI yang anti-Teologi Pembebasan dan Fransikus yang datang dari persemaian Teologi Pembebasan Amerika Latin itu.

Ketika menafsirkan dan mendiagnosis secara teologis sejauh mana Vatikan II berdampak dan terserap serta berpengaruh ke luar dunia dan dalam kehidupan menggereja, perlu dipertimbangkan unsur-unsur geografis dan kultural tertentu. Konon Eropa sudah bukan tanah subur bagi Katolisitas. Tanah ini sudah kehabisan humus dan perlu digarap ulang bentuk religiusitasnya, dan yang pasti tidak seperti digambarkan oleh Vatikan II. Amerika Serikat, anehnya, menjadi harapan yang mencerahkan untuk Katolisitas di masa yang akan datang. Amerika Latin yang sudah menyimpang ke gerakan pentakostal dan karismatik juga sudah dianggap menjauh dari tradisi Vatikan II. Sementara itu Asia dan Afrika sebagai tanah misi masih bergulat dengan pro-kontra dalam bidang inkulturasi. Vatikan II bukan sekedar 'juklak' yang dapat diterapkan begitu saja dalam setiap kondisi semacam itu.

Akan mengarah ke mana Vatikan II rupanya masih akan ditentukan oleh kelompok-kelompok (circles) seperti Nouvelle Theologie, Communio, dan Concilium. Kelompok-kelompok ini sebagai suatu gerakan menentukan visi teologis untuk ikut mengarahkan Gereja Katolik seperti apa yang 
ideal untuk masa kini dan masa yang akan datang. Konstelasi antara kelompok-kelompok ini ikut menentukan arah dan tren teologi. Masa depan Katolisisme, karenanya, tidak sesempit yang diteropong oleh lensa mikro Vatikan II. Masa depan humanisme menantang lebih luas dan kompleks serta mendesak daripada sekadar berkutat dengan pemasalahan dialog dengan agama lain secara apologetik, atau meributkan masalah tradisionalisme, liberalisme, dan sekularisme. Masa depan manusia tergantung pada masalah ekologis, pemanasan global, terorisme, dan kesenjangan antara orang miskin dan kaya. Permasalah makro-etik lebih mendesak daripada mikro-etik. Tantangan Gereja Katolik adalah menciptakan "a better world for all" atau Kerajaan Allah yang bersifat inklusif namun serentak pluralistik.

\section{Bibliography}

Benedict XVI, Pope. Light of the World; The Pope, the Church, and the Sign of Times. San Francisco: Ignatius Press, 2010.

Congar, Yves, O.P. The Church That I Love. New Jersey: Dimension Books, 1969.

De Lubac, Henri. The Splendor of the Church. San Francisco: Ignatius Press, 1999.

Francis, Pope. The Joy of the Gospel; Evangelii Gaudium. Roma: Vatican Press, 2013.

Müller, Gerhard Ludwig. (Wawancara) dalam Frankfurter Allgemaine Zeitung (FAZ); Gerhard Ludwig Müller, catholic-hierarchy.org.

Sullivan, Francis A., SJ. Creative Fidelity: Weighing and Interpreting Documents of the Magisterium. Goldenbridge Dublin: Gill and Macmillan, 1996. . Salvation Outside the Church? Tracing the History of the Catholic Response. London: Goffrey Chapman, 1992.

Smith, James K.A. Who's Afraid of Postmodernism? Taking Derrida, Lytard, and Foucault to Church, Michigan: Baker Academic, 2006.

Villa, Luigi. Paul VI Beatified? Oconomosoc, WI: The Apostolate of Our Lady of Good Sucess, 2009. 


\section{Endnotes:}

1 Tulisan ini dibuat dalam kerangka refleksi sebagai seorang Katolik; kata 'kita' menunjuk kepada orang-orang Katolik.

2 Istilah diakronikos (diachronos) - dia dan chronos; artinya 'melalui waktu.' Istilah ini dipakai dalam studi yang berhubungan dengan linguistik Saussurian yang biasa dihubungkan dengan istilah synchronic. Istilah ini ingin saya gunakan dalam konteks pembahasan secara hipotetikal bahwa ada hubungan kausal antara individuindividu yang merencanakan, membuat draft (lineamenta), dan paus siapa yang menjadi orang nomor satu dalam mengakomodasi pemikiran secara decisive, begitu pula polarisasi gerakan-gerakan atau 'lingkaran' yang konservatif dan liberal serta sejumlah dokumen pasca-konsilier. Unsur-unsur tersebut dalam waktu tertentu akan menentukan suatu kelanjutan yang tidak jauh dari kondisi itu. Ada sinkronisitas yang dapat ditafsirkan sebagai berkaitan erat, paling tidak, dianggap menunjukkan probabilitas yang lebih tinggi. Dengan kata lain, pelaku sejarah secara implisit atau eksplisit turut andil dalam menentukan perubahan, kemunduran, atau kemandegan.

3 Lih. Francis A. Sullivan, SJ., Creative Fidelity: Weighing and Interpreting Documents of the Magisterium (Goldenbridge Dublin: Gill and Macmillan, 1996) 162-166.

4 Lih. Luigi Villa, Paul VI Beatified? (Oconomosoc, WI: The Apostolate of Our Lady of Good Sucess, 2009) 7-12.

5 Lih. Francis A. Sullivan, SJ., Salvation Outside the Church? Tracing the History of the Catholic Response, (London: Goffrey Chapman, 1992) 182-189.

$6 \quad$ Ibid., 187.

7 Lih. Yves Congar, O.P., The Church That I Love (New Jersey: Dimension Books, 1969).

8 Lih. tulisan Eugene Cullen Kenedy dalam NCR (National Catholic Report); 6 Januari 2014.

9 Lih. John Thavis, “The Pope’s ‘reform’ Project has Already Begun,” http://www. johnthavis.com/; posted on Wed, March 27, 2013.

10 Pope Francis, The Joy of the Gospel; Evangelii Gaudium (Roma: Vatican Press, 2013).

11 Henri de Lubac, The Splendor of the Church (San Francisco: Ignatius Press, 1999).

12 Benedict XVI, Light of the World; The Pope, the Church, and the Sign of Times (San Francisco: Ignatius Press, 2010) 27-30.

13 James K.A. Smith, Who's Afraid of Postmodernism? Taking Derrida, Lytard, and Foucault to Church (Michigan: Baker Academic, 2006).

14 Wawancara Gerhard Ludwig Müller dalam Frankfurter Allgemaine Zeitung (FAZ); lihat juga dalam Gerhard Ludwig Müller, catholic-hierarchy.org. 